Article

\title{
Policies, Practices, and Attitudes toward Inclusive Education: The Case of Greece
}

\author{
Marios A. Pappas * (iD, Chara Papoutsi ${ }^{(D)}$ and Athanasios S. Drigas \\ Institute of Informatics \& Telecommunications, National Center for Scientific Research 'Demokritos', \\ 15341 Agia Paraskevi, Greece; papoutsi.xara@yahoo.com (C.P.); dr@iit.demokritos.gr (A.S.D.) \\ * Correspondence: mpap@iit.demokritos.gr
}

Received: 28 April 2018; Accepted: 31 May 2018; Published: 4 June 2018

\begin{abstract}
Inclusive education is now firmly established as the main educational policy for children with special educational needs and disabilities, which emerges as the mean of creating an inclusive society in which equal opportunities are provided. However, there are concerns expressed on the effect of such a change in the educational system and on how possible it is to make this a reality. The concerns and objections of educators toward inclusion are mainly based on the diversity of learning disabilities, the learning outcomes that could be generated by applying this practice, and the lack of confidence of teachers to teach in an inclusive environment. In this study, we examine teachers' attitudes toward inclusive education, while at the same time, we analyze current inclusive policies and practices in the Greek educational system. Results revealed that teachers have generally positive attitudes toward inclusion. However, they indicated some issues and barriers to the implementation of inclusion. We consider that policy-makers in Greece should target educator training and increase funding for education.
\end{abstract}

Keywords: inclusive education; special education needs; education policy

\section{Introduction}

The importance of education is multifaceted and extends to the entire range of activities of the individual and society. Education is related to both the development of the individual and his/her inclusion in social and economic life. Undoubtedly, it should be mentioned that education is a fundamental right of every human being. The human right to education is recognized and safeguarded by international organizations and national institutions (Armstrong et al. 2011). Philosophies regarding the education of children with learning difficulties and/or disabilities have changed dramatically over the last two decades and several countries have implemented policies that foster the integration and, more recently, inclusion of these students into mainstream environments. Indicatively, we can mention the United Nations Convention on Human Rights of 2007, and several international conventions of UNESCO. In particular, the Warnock Report (Warnock Committee 1978) and the Salamanca Statement (1994) are considered as the most important papers written for children's rights and showed the way for the legal recognition of inclusive education. Four decades after the publication of the Warnock report, and during this period, various studies have focused on the concept, implementation, and future challenges of inclusive education.

Proponents of inclusive education claim that there is need for immediate radical changes and reforms in the educational system structures, such as changes and adjustments of the curriculum in order to ensure equal learning opportunities for all (Ainscow 2005). Furthermore, they highlight the need for teachers' training in inclusive practices (Persson 2006). However, inclusive education is still a controversial concept, as researchers and educators have expressed concerns about the effects of inclusion (Sharma et al. 2008). Critics of inclusion claim that the inclusive educational model does not 
have the desired outcomes for children with diverse educational needs (Anastasiou and Kauffman 2011) Furthermore, lack of confidence in teaching pupils with special educational needs, as well as years of teaching experience, could affect teachers' attitudes toward inclusion (De Boer et al. 2011).

According to Greek educational legislation, since 2008, students with SEN could attend general classes, with or without parallel support, based on the recommendation of the national diagnosis and support centers. According to the European Agency for Development in Special Needs Education (2010), there are 29,954 school-aged pupils in Greece who have SEN. From these pupils, 7483 attend special schools, while 22,471 attend special classes in mainstream schools. The Greek educational system offers undergraduate and postgraduate studies for inclusive education teachers. The Department of Special Needs at the University of Thessaly offers special education studies to its students. The graduates of this department can obtain a university degree in special education. Furthermore, the Department of Educational and Social Policy of the University of Macedonia in Thessaloniki offers a university degree in SEN (Brown 2016).

This research aims to outline the current situation in Greece regarding inclusive education. Therefore, we conducted a desk research in order to record the policies and practices related to inclusion in the Greek educational system. Then, a questionnaire survey was conducted in order to investigate attitudes of Greek teachers toward inclusive education and the factors affecting their attitudes.

\section{Literature Review}

Teachers' attitudes toward inclusion are often not based on ideological arguments but rather on practical concerns about how inclusive education can be implemented (Warnock et al. 2010). Such studies have provided vital information and source. A literature review by Avramidis and Norwich (2002) showed that teachers have an overall positive attitude toward the inclusion of children with special needs into regular school programs. Another systematic review revealed that attitudes of teachers are directly influenced by the type and severity of children's dysfunctions. It has also been concluded that these beliefs are neutral to negative toward inclusion since educators feel they do not have the knowledge and the proper qualifications to educate children with Special Educational Needs and appear to have no self-confidence to do so (De Boer et al. 2011).

\subsection{Lack of Confidence}

The majority of teachers expresses positive attitudes toward inclusion of students with SEN, implying at the same time the need for appropriate teacher training on the individual needs of students with disabilities (Ahmme et al. 2013; Bhatnagar and Das 2014). Teachers acquire increased competence and confidence as a result of increased training in the field of inclusive education (Subban and Sharma 2005). Adequate knowledge, instructional techniques, training, and curricular adaptations contribute to increased confidence, and that leads to positive influences and attitudes in the field of inclusive education. In addition, previous teaching experience with students with SEN could positively affect teachers' attitudes toward inclusion and help them feel more comfortable during the whole learning process (Batsiou et al. 2008; Findler et al. 2007; Malinen et al. 2012; Tsakiridou and Polyzopoulou 2014; Zoniou-Sideri and Vlachou 2006). Teachers with high levels of confidence are prompt to modify the educational material so that it suits on students' individual learning needs and provide special assistance to low achieving students. Moreover, they do not demonstrate anxiety because of their high levels of self-esteem, and that is reflected in the whole teaching procedure.

Teachers could take active role in their development by attending specialized training sessions (Knight 2002). There are studies indicating that teachers' confidence on teaching students with SEN is significantly affected when they receive direct training (Hornby 1999; Leatherman 2007; Siegel and Jausovec 1994, Kim 2011). A properly formulated curriculum, better training on special education, cooperation by all stakeholders, new oriented teaching methods, and carefully structured field experiences are very important factors that affect the self-efficacy and confidence of the teachers and form positive attitudes from the part of the teachers toward inclusive education (Robinson 2017). 


\subsection{Inclusion for All?}

Research shows that the type of disability is an important factor that affects teachers' attitudes toward inclusion (Hofman and Kilimo 2014; De Boer et al. 2012). In the study of Avramidis and Kalyva (2007), teachers felt that only children with mild special educational needs could attend the general school. Teachers pointed out that they feel inadequate to teach children with brain damage, autism, and sensory disorders.

Teachers tend to develop positive attitudes toward students with social difficulties, they are less concerned about students with behavioral and academic difficulties, but they consider students with physical disabilities as less confronting in general schools (Bornman and Donohue 2013; Sharma et al. 2003; Yada and Savolainen 2017). Teachers would accept with convenience the inclusion of students with mobility impairments or visual impairments in mainstream class, but they will not have the same visual if inclusion was related to students who exhibit extreme behavior problems (Hodkinson 2006). In many schools that have adopted inclusive policy in the UK, they work in parallel within the school special units for children with behavioral problems, or they are sent for a long time in special schools (Hodkinson and Devarakonda 2009).

According to the findings of a study of empirical research conducted in Austria, teachers consider the inclusion of students with mental retardation more difficult than the inclusion of mobility-impaired students or students with learning difficulties (Gebhardt et al. 2011). Strengthening these perceptions, school teachers in Botswana $(n=103)$ are more cautious to include students with hearing impairments or students who use Braille or sign language, while they could agree with the inclusion of shy and withdrawn students or those with frequent absences (Chhabra et al. 2010).

\subsection{Learning Benefits and Consequences}

Supporters of inclusion highlight the issue, referring not only to the right to education for all but also to the multiple benefits for children from this process. According to teachers' beliefs, inclusion of students with disabilities could benefit both disabled and typically developing peers in terms of the social, emotional, and academic outcomes (Ajuwon 2008; Gilmore et al. 2003; Katz and Mirenda 2002). Students with learning disabilities seem to benefit from their enrollment in inclusive classrooms in terms of their course grades in Language arts, Mathematics, Sciences, and Social Sciences (Rea et al. 2002). Ruijs et al. (2010) examined whether students without disabilities were affected by the inclusive learning environment. They used data from a representative sample of 27,745 primary school students, who had no learning disabilities. For the assessment of students throughout the duration of the project, researchers used linguistic and numerical tests and IQ tests. Analysis of the results showed a particular interest, revealing that there was no difference in the performance of students attending the course in inclusive classes with students attending mainstream classes. Another survey in Switzerland (Dessemontet et al. 2011) investigated the effectiveness of inclusion of students with mental retardation and its effects on the academic progress of their peers. Results showed that inclusion had no negative impact on learning development of the other children in the classroom. Instead, the performance of children with mental retardation proved as good with their studies at a special school, especially in the course of language.

However, negative attitudes are also presented in terms of the outcomes of the inclusion for students with specific learning disabilities and for typically developing students (Savolainen et al. 2012). Lindsay (2003), an English teacher and former supporter of full inclusion, claims that inclusive education does not provide clear evidence for the expected learning benefits. As revealed from a study with 840 participants in Germany, parents of children with disabilities and who were already in special schools expressed their negative attitudes, arguing that their children in the mainstream school would not have the necessary support, although they accepted the advantages of inclusive education (Gasteiger-Klicpera et al. 2013). In 2007, 125 college students, with teaching experience, participated in a survey designed to investigate their attitudes towards inclusion. Participants were selected from eight different departments: Arts, History, English, Geography, Home Economics, Music, Technology, and 
Physical Education. A high percentage (44.8\%) of the respondents claimed that inclusion of children with diverse educational needs in the mainstream class is unfair for children with typical development who may be left behind, while 32.4\% disagreed with this statement (Lambe and Bones 2007).

\subsection{Barriers}

Despite the fact that teachers generally develop positive attitudes toward inclusion, they express concerns originated from insufficient training and lack of appropriate educational material for the education of students with SEN (Gal et al. 2010; Glazzard 2011; Scruggs and Mastropieri 1996). In addition, many teachers state that they do not have access to appropriate educational equipment in order to adequately teach students with SEN regarding their specific type of disability. Lack of training, shortage of teaching and learning materials, large number of pupils in classes, large number of periods per teacher, shortage of time per period, poor governmental and parental support, poor working environment and difficulties in supporting pupils with different disabilities especially in primary schools, poor cooperation with other teachers, special staff and generally with the various public and private entities are some of the underlined deterrent factors that could have negative impact on teachers' beliefs about inclusion of students with SEN in mainstream schools (Amr et al. 2016; Polat 2011; Rakap and Kaczmarek 2010; Anastasiadou 2016; Leatherman and Niemeyer 2005). Provision of suitable teaching materials and other supporting services for teachers seem to encourage teachers to develop more positive attitudes toward inclusion of students with disabilities. Teachers in inclusive schools also need support from parents, school directors, educational stakeholders, and governmental bodies.

\subsection{Educational Policies and Practices in Greece}

Over the past 20 years, there is an evidence of improvement in Greece in the field of disability and special education. Initially, the decisions taken were borrowed from already applied models of social welfare and education in foreign countries. Specialized educational and support staff is strengthened, while at the same time, the number of inclusive classes increases each year (Zoniou-Sideri et al. 2006). Law 1143/81 was the first comprehensive law in the history of Special Education in Greece (together with the Supplementary Presidential Decree 603/82) (Tafa and Manolitsis 2003). Law 1143/81 and Presidential Decree 603/82 were criticized because they strengthened the separation between normal and abnormal individuals, they classified students in 12 categories of problematic individuals according to their disability, and they marginalized Special Education from the core of General Education. Law 1566/1985 was one of the most important laws of special education that for the first-time institutionalized education in Greece. However, it was criticized as it was considered to be essentially a simple compilation of the previous law. On 14 March 2000, another law was voted by the Greek parliament (Law 2817/2000), in which was given emphasis on the common educational needs of disabled students and not on the clinical reasoning of their disabilities. According to this law, special schools should be limited only to children with severe and multiple disabilities. In the same direction was also the redefinition of diversification, diagnosis, and support centers for students with SEN (KEDDY in Greek) with the law 3699/2008 (Bablekou and Kazi 2016). With the revision of the law on special education, there has been a gradual improvement in the way that disabled people are treated in education. The inclusion of disabled people into the education system has started to improve, and their accessibility to buildings and other facilities has made some progress. The teaching staff became more specialized due to special sections of Special Education for Primary Education as well as postgraduate Special Education Departments for Secondary Education and generally for all sectors of teachers. While improvements have been made, progress on the issue of inclusion has started to lag.

Greece, despite the supportive inclusive legislation, still faces considerable barriers toward the implementation of inclusion promoting a divisive policy towards children with specific learning difficulties and disabilities (Fyssa and Vlachou 2015; Fyssa et al. 2014). According to the information 
from the European Agency for Development in Special Needs Education, the student population in 2012 was 1,131,901 in Greece, including 801,101 students in primary education and 330,800 students in secondary education. Based on additional data from the same source, $73.17 \%(n=26,350)$ of the students with specific learning difficulties and disabilities were enrolled in mainstream schools, as well as $21.83 \%$ ( $n=7861)$ of those children attended special school units. The remaining $5 \%$ of pupils ( $n=1800)$ were educated in general classrooms, where parallel instruction was offered (European Agency for Development in Special Needs Education 2012). Discrimination suffered by people with disabilities starts from their pre-school age and continues at all the levels of education. Students with disabilities who manage to participate in the educational system gave up their attempts because of that discrimination. Poor quality education is a kind of discrimination for people with special educational needs. Many schools lack the proper equipment, do not provide the necessary logistical infrastructure, and are not equipped with specially qualified teaching staff despite the legislative arrangements, and that discourages these people and their families and discards them from the school system. The lack of technological assistance and the failure to ensure digital accessibility for some disability categories increases the existing differentiation. A high percentage of teachers believe that financial provisions and infrastructure in Greece are inadequate for the successful implementation of inclusion in education. Construction of new school units, remodeling of old ones, and the purchase of special equipment are going to enhance the implementation of inclusive education (Koutrouba et al. 2008).

From the above, it becomes clear that despite the general effort for a qualitative upgrade of the Greek educational system targeted to inclusion (Antoniou et al. 2009) and despite the fact that emphasis is placed upon the change of educational structure at all levels, the progress in Greece remains low in comparison to the average progress marked in the European Union. Teachers in Greece seem to be critical about the political effort toward inclusive education ( $\mathrm{O}^{\prime}$ Hanlon 2013). In Greece, despite the fact that Special Education has been organized for more than 25 years, there have not yet been developed adequate curricula that respond to all the specific needs of the students. In addition, equal access to education is disputed to the extent that the same curriculum does not apply in all kind of students. (Lambropoulou 2004). Therefore, there is an urgent need to step up the efforts, in order to overlap barriers toward the implementation of inclusion in education. The need for further reinforcement of access in all the educational levels for disabled children is also highlighted in the "National Report of Strategy for the Social Protection and Social Inclusion for the years 2008-2010" and with the voting of the law on compulsory Special Education (Law: N3699/2008).

\section{Methods}

In order to investigate policies and practices towards inclusion in Greece, we conducted a desk research. Based on this, we represent the main inclusive policies and practices of the Greek educational system, as emerged from the desk research. In addition, we examine the attitudes of teachers in Greece toward inclusive education, through an online survey. In particular, our study aims to answer the following questions:

Does level of confidence on teaching students with disabilities, existence of a disabled family member, as well as gender, affect teachers' attitudes toward inclusion?

According to teachers' beliefs, students with specific learning difficulties and disabilities will benefit from the inclusion?

According to teachers' beliefs, typically developing students could benefit in an inclusive environment?

Which are the main barriers toward inclusion, according to teachers' beliefs?

\subsection{Measures}

For data collection we developed and administered the questionnaire "Teachers' beliefs and attitudes toward Inclusive Education" (Appendix A). A literature review preceded the questionnaire, in order to finalize research objectives and select the variables to be controlled. A pilot questionnaire 
was initially administered to a limit number of people with different characteristics in order to establish the effectiveness of the designed tool. Testing of the questionnaire design helped us to ensure that the used terms were easily perceived, as well as that the way of drafting the questions allows the collection of desired data. The questionnaire was divided in five sections. The first section contained demographic questions such as gender, age, and teaching level. The second was focused on teachers' confidence regarding teaching students with disabilities. Section three focused on teachers' attitudes toward inclusion in relation to the different kinds of disability. Section four contained questions related to the learning outcomes and possible implications of inclusion for students with disabilities and for typically developing students. The last section of the questionnaire was focused on possible barriers to inclusion in Greek educational system. Section 2, Section 3, Section 4, and Section 5 contained 34 statements which respondents were asked to rank on a five-level Likert scale, in order to avoid forced choice bias ( 1 = Strongly Disagree, 2 = Disagree, $3=$ Neutral, $4=$ Agree, $5=$ Strongly Agree) . Respondents could add additional comments on inclusive education at an open-ended question if not covered by the previous questions.

\subsection{Participants}

Study participants were teachers who attended the annual circle of seminars entitled "Specialization in Special Education and Information \& Communication Technologies" provided by the National Center for Scientific Research "Demokritos" in Athens, Greece. A questionnaire was administered to 234 teachers via e-mail and was at their disposal for 14 days. Data from 147 questionnaires (response rate 62.8\%) were included in the statistical analysis (Table 1). More than half of the participants were primary school teachers $(n=79,54 \%)$, while $75 \%$ of the participants $(n=110)$ were female.

Table 1. Demographic data of the participants.

\begin{tabular}{lcc}
\hline \multicolumn{1}{c}{ Demographic } & Frequency & Percentage (\%) \\
\hline Gender & 37 & \\
Male & 110 & 75 \\
Female & & \\
\hline Age & 50 & 34 \\
$20-30$ & 49 & 33 \\
$31-40$ & 20 & 14 \\
$41-50$ & 28 & 19 \\
More than 51 & & \\
Teaching Level & 15 & 10 \\
Kindergarten & 79 & 54 \\
Primary School & 40 & 27 \\
Secondary School & 13 & 9 \\
Higher Education & & 21 \\
\hline Disabled in the family & 31 & 79 \\
Yes & 116 & \\
No & &
\end{tabular}

\subsection{Data Analysis}

For the analysis of the collected data we used IBM SPSS Statistics Subscription (Armonk, New York, NY, USA), version 1.0.0.800. Descriptive statistics (mean \& standard deviation) were used to evaluate teachers' attitudes towards inclusion, as well as their beliefs about expected outcomes of inclusion and possible barriers to inclusion. Independent groups $t$-test was conducted in order to evaluate significant differences in teachers' attitudes towards inclusion, in terms of gender. Finally, one-way analysis of variance (ANOVA) was used to compare means between independent groups 
(i.e., groups based on gender, existence of a disabled person in the family or level of confidence on teaching students with disabilities).

\section{Results}

\subsection{Reliability and Validity of the Questionnaire}

For the internal consistency of the questionnaire, Cronbach's Alpha correlations were calculated. Reliability for the whole questionnaire was acceptable $(\alpha=0.932)$ advocating the reliability of the questionnaire. Specifically, for the questions referring to attitudes toward inclusion, Cronbach's was 0.944, while for questions referring to expected outcomes of inclusion, it was 0.936 . In order to evaluate questionnaire's structural validity, Pearson correlation coefficients were applied amongst questions referring to attitudes toward inclusion (Table 2) and questions referring to expected outcomes of inclusion (Table 3). All correlation coefficients were high and statistically significant, advocating the validity of the questionnaire.

Table 2. Correlation coefficients between questions referring to attitudes toward inclusion.

\begin{tabular}{|c|c|c|c|c|c|c|c|c|c|c|c|c|}
\hline & Q 6.1 & Q 6.2 & Q 6.3 & Q 6.4 & Q 6.5 & Q 6.6 & Q 6.7 & Q 6.8 & Q 6.9 & Q 6.10 & Q 6.11 & Q 6.12 \\
\hline Q 6.1 & 1.000 & & & & & & & & & & & \\
\hline Q 6.2 & $0.566^{* *}$ & 1.000 & & & & & & & & & & \\
\hline Q 6.3 & $0.580 * *$ & $0.887^{* *}$ & 1.000 & & & & & & & & & \\
\hline Q 6.5 & $0.465 * *$ & $0.546^{* *}$ & $0.542 * *$ & $0.676^{* *}$ & 1.000 & & & & & & & \\
\hline Q 6.6 & $0.524^{* *}$ & $0.463^{* *}$ & $0.520 * *$ & $0.607^{* *}$ & $0.727^{* *}$ & 1.000 & & & & & & \\
\hline Q 6.7 & $0.436 * *$ & $0.433 * *$ & $0.448^{* *}$ & $0.541 * *$ & $0.798 * *$ & $0.649 * *$ & 1.000 & & & & & \\
\hline Q 6.9 & $0.444^{* *}$ & $0.550 * *$ & $0.579 * *$ & $0.640 * *$ & $0.625 * *$ & $0.579 * *$ & $0.587 * *$ & $0.752 * *$ & 1.000 & & & \\
\hline Q 6.10 & $0.409^{* *}$ & $0.334^{* *}$ & $0.406^{* *}$ & $0.505^{* *}$ & $0.599 * *$ & $0.536^{* *}$ & $0.619^{* *}$ & $0.530 * *$ & $0.601 * *$ & 1.000 & & \\
\hline Q 6.11 & $0.557^{* *}$ & $0.565^{* *}$ & 0.567 ** & $0.604^{* *}$ & $0.619^{* *}$ & $0.650 * *$ & 0.570 ** & 0.562 ** & 0.657 ** & $0.637^{* *}$ & 1.000 & \\
\hline Q 6.12 & $0.508 * *$ & $0.606^{* *}$ & $0.621 * *$ & $0.684^{* *}$ & $0.600 * *$ & $0.605 * *$ & $0.562 * *$ & $0.739 * *$ & $0.773^{* *}$ & $0.623^{* *}$ & $0.698^{* *}$ & 1.000 \\
\hline
\end{tabular}

** Correlation is significant at the 0.01 level.

Table 3. Correlation coefficients between questions referring to outcomes of inclusion.

\begin{tabular}{|c|c|c|c|c|c|c|c|c|c|c|}
\hline & Q 7.1 & Q 7.2 & Q 7.3 & Q 7.4 & Q 7.5 & Q 8.1 & Q 8.2 & Q 8.3 & Q 8.4 & Q 8.5 \\
\hline Q 7.1 & 1.000 & & & & & & & & & \\
\hline Q 7.2 & $0.905^{* *}$ & 1.000 & & & & & & & & \\
\hline Q 7.3 & $0.857^{* *}$ & $0.916^{* *}$ & 1.000 & & & & & & & \\
\hline Q 7.4 & $0.494^{* *}$ & $0.553^{* *}$ & $0.611^{* *}$ & 1.000 & & & & & & \\
\hline Q 7.5 & $0.592 * *$ & $0.630^{* *}$ & $0.595^{* *}$ & $0.615^{* *}$ & 1.000 & & & & & \\
\hline Q 8.1 & 0.436 ** & 0.449 ** & $0.485^{* *}$ & $0.544^{* *}$ & $0.435^{* *}$ & 1.000 & & & & \\
\hline Q 8.2 & $0.607 * *$ & $0.636^{* *}$ & $0.646^{* *}$ & $0.489 * *$ & $0.593 * *$ & $0.485^{* *}$ & 1.000 & & & \\
\hline Q 8.3 & $0.579 * *$ & 0.557 ** & $0.560^{* *}$ & $0.463^{* *}$ & $0.593^{* *}$ & $0.375^{* *}$ & $0.865^{* *}$ & 1.000 & & \\
\hline Q 8.4 & $0.546^{* *}$ & $0.575^{* *}$ & $0.563^{* *}$ & $0.522 * *$ & 0.652 ** & $0.565^{* *}$ & $0.711^{* *}$ & $0.722 * *$ & 1.000 & \\
\hline Q 8.5 & $0.590 * *$ & $0.600^{* *}$ & $0.631^{* *}$ & $0.502 * *$ & $0.535^{* *}$ & $0.393^{* *}$ & $0.828^{* *}$ & $0.785 * *$ & $0.728 * *$ & 1.000 \\
\hline
\end{tabular}

** Correlation is significant at the 0.01 level.

\subsection{Attitudes Towars Inclusion}

Question 6 targeted to examine teachers' attitudes toward inclusion of students with different types of disabilities (Table 4). Participants strongly agree with the inclusion of students with mobility problems $(M=3.93, S D=1.054)$ or specific learning disabilities $(M=3.6, S D=1.209)$, but they seem more cautious with the inclusion of students with mental retardation $(\mathrm{M}=2.54, \mathrm{SD}=1.207)$ or students with genetic syndromes $(\mathrm{M}=2.75, \mathrm{SD}=1.243)$. One-way ANOVA was used to examine the relationship between gender, existence of disabled person in family, or level of confidence on teaching students with disabilities and attitudes toward inclusion. Generally, women had more positive attitudes compared to men, with the case of students in the autism spectrum being the only one that shows statistically 
significant differences between group means $\mathrm{t}(145)=2.51, p=0.13$. According to the results, existence of a disabled person in the family was significantly correlated to participants' attitudes towards inclusion of children with a syndrome, $\mathrm{F}(1,145)=4.437, p=0.037, \eta^{2}=0.030$, or children with autism spectrum, $\mathrm{F}(1,145)=5.986, p=0.016, \eta^{2}=0.040$. Furthermore, participants' level of confidence on teaching students with disabilities was significantly correlated to the inclusion of students with hearing impairments, $\mathrm{F}(4,142)=4.044, p=0.004, \eta^{2}=0.102$. visual impairments $\mathrm{F}(4,142)=5.703, p<0.001$, $\eta^{2}=0.138$, speech impairments $\mathrm{F}(4,142)=3.317, p=0.012, \eta^{2}=0.085$, comprehension problems $\mathrm{F}(4,142)$ $=3.079, p=0.018, \eta^{2}=0.080$, mental retardation $\mathrm{F}(4,142)=5.530, p<0.001, \eta^{2}=0.135$, autism spectrum $\mathrm{F}(4,142)=4.673, p=0.001, \eta^{2}=0.116$, specific learning disabilities $\mathrm{F}(4,142)=4.851, p=0.001, \eta^{2}=0.120$ and syndromes $\mathrm{F}(4,12)=3.903, p=0.005, \eta^{2}=0.099$.

Table 4. Attitudes toward inclusion based on gender.

\begin{tabular}{|c|c|c|c|c|c|c|c|}
\hline \multirow[b]{2}{*}{ Kind of Disability } & \multicolumn{2}{|c|}{ Male } & \multicolumn{2}{|c|}{ Female } & \multicolumn{3}{|c|}{$t$-test } \\
\hline & $\mathbf{M}$ & SD & $\mathbf{M}$ & SD & $\mathbf{t}$ & df & $\mathrm{p}$ \\
\hline Mobility problems & 3.81 & 1.076 & 3.96 & 1.049 & 0.762 & 145 & 0.447 \\
\hline Hearing impairments & 2.86 & 0.976 & 3.10 & 1.248 & 1.177 & 145 & 0.243 \\
\hline Visual impairments & 2.68 & 1.107 & 3.01 & 1.281 & 1.414 & 145 & 0.159 \\
\hline Speech impairments & 3.16 & 1.041 & 3.48 & 1.179 & 1.467 & 145 & 0.144 \\
\hline Behavioural problems & 3.27 & 1.018 & 3.42 & 1.192 & 0.676 & 145 & 0.500 \\
\hline Comprehension problems & 3.41 & 1.142 & 3.61 & 1.059 & 0.992 & 145 & 0.323 \\
\hline Aggressive behaviour & 3.11 & 0.843 & 3.17 & 1.270 & 0.351 & 145 & 0.726 \\
\hline Mental retardation & 2.30 & 1.151 & 2.62 & 1.219 & 1.404 & 145 & 0.162 \\
\hline Autism spectrum & 2.41 & 1.189 & 2.99 & 1.238 & 2.513 & 145 & $0.013^{*}$ \\
\hline Emotional disorder & 3.41 & 1.235 & 3.18 & 1.190 & 0.979 & 145 & 0.329 \\
\hline Specific learning disabilities & 3.43 & 1.345 & 3.65 & 1.161 & 0.967 & 145 & 0.335 \\
\hline Syndromes & 2.54 & 1.120 & 2.82 & 1.279 & 1.177 & 145 & 0.241 \\
\hline
\end{tabular}

\subsection{Expected Outcomes of Inclusion}

Questions 7 and 8 examined teachers' beliefs on the outcomes of inclusion for children with specific learning difficulties and disabilities and for typically developing students. As findings indicated, participants believe that students with disabilities will benefit from inclusion in terms of their social development and behavior $(\mathrm{M}=3.90, \mathrm{SD}=0.982)$, social interaction $(\mathrm{M}=3.87, \mathrm{SD}=1.042)$, and development of their social skills $(\mathrm{M}=3.80, \mathrm{SD}=1.038)$. On the other hand, participants seem to believe that academic performance of students with disabilities will not benefit from inclusion $(\mathrm{M}=2.90, \mathrm{SD}=1.094)$.

At the same time, participants claim that typically developing students could benefit from the inclusion of students with disabilities in terms of their acceptance of diversity $(\mathrm{M}=4.08, \mathrm{SD}=1.017)$, social consciousness $(\mathrm{M}=4.02, \mathrm{SD}=0.925)$, and their development of empathy $(\mathrm{M}=4.01, \mathrm{SD}=1.037)$. However, in this case also, participants do not expect significant improvement in academic performance of typically developing students $(\mathrm{M}=3.04, \mathrm{SD}=1.158)$.

\subsection{Barriers to Inclusion}

Finally, in question 9, teachers were asked to indicate the factors they consider as most important for the proper implementation of inclusive practices in Greece. As findings did revealed, lack of qualified educational staff $(\mathrm{M}=4.54, \mathrm{SD}=0.685)$, large number of students in classrooms $(\mathrm{M}=4.37$, $\mathrm{SD}=0.804)$, incomplete funding $(\mathrm{M}=4.41, \mathrm{SD}=0.882)$, and lack of appropriate infrastructure in school units $(\mathrm{M}=4.24, \mathrm{SD}=0.880)$ are considered from the participants as the most possible barriers to inclusion. As further barriers toward the successful inclusion are considered parents' attitudes to inclusion $(\mathrm{M}=4.15, \mathrm{SD}=0.805)$, teachers' reluctance $(\mathrm{M}=3.95, \mathrm{SD}=1.133)$, educational legislation in Greece $(\mathrm{M}=3.83, \mathrm{SD}=1.113)$, and the curriculum $(\mathrm{M}=3.70, \mathrm{SD}=1.043)$. 


\section{Discussion and Conclusions}

The Warnock Report of 1978 is a landmark for the education of children with disabilities. However, in 2005, Warnock published a pamphlet entitled "Special Educational Needs: A New Look," which raised some controversial issues on the 1978 report. According to that, the concept of inclusion, which is understood as the right of every child to be educated in a regular school, is a catastrophic legacy and results in many children with emotional needs being excluded from joint learning. This is evident in children with emotional and behavioral needs and people with autism. For these children, integration efforts should be reviewed, and there should be the possibility of existence of small special schools. Teachers seem to be a key factor in successful inclusion, as they have an important position in education (Forlin and Chambers 2011). They serve as intermediaries between the state, various stakeholders in education, parents, policies and legislation, and the students, as they are responsible for implementing policy in inclusive environments and sharing and promoting inclusion principles in the classroom. When the goal is full inclusion, it is essential for teachers to be competent, willing to work with children with special needs, and well informed and aware of the critical aspects of both Inclusive Education and Special Educational Needs.

Teachers who participated in the study seem to support the inclusion of children with specific learning difficulties and disabilities in the mainstream classrooms, indicating at the same time the benefits of inclusion for them and for typically developing children. However, they seem more cautious for some types of disabilities, such as mental retardation, autism spectrum, and genetic syndromes. International surveys support our findings that women are more supportive on inclusion and more tolerant on students with special educational needs, unlike male colleagues (Alghazo et al. 2004; Romi and Leyser 2006). On the contrary, there are other surveys that reported no effect on gender (Alghazo et al. 2003; Woodcock 2013). Furthermore, as far as age is concerned, younger teachers tend to adopt more favorable views toward the inclusion of students with special educational needs (Gal et al. 2010; Subban and Sharma 2006), while some other studies reported no significant effect of teachers' age on having inclusive attitudes (Ellins and Porter 2005). Another variable that is being examined in relation to the perception of the educators about the inclusion education is whether they have a person with disabilities in their family environment. This variable examines the impact of teachers' opinion on this and if they are more sensitive to these issues due to that fact. Studies have showed that teachers who have been exposed to people with disabilities (i.e., friend or family member) are more open to inclusion (Forlin et al. 2009; Gething et al. 1997), whereas other studies do not report any influence of prior exposure to disability. Finally, as revealed from the results, lack of qualified educational staff, overcrowding of children in classrooms, and incomplete funding are the main barriers to the implementation of inclusive education in Greece, according to teachers' beliefs (Coutsocostas and Alborz 2010).

In Greece, despite the legal provisions for implementing inclusive education, what is mainly applied in practice is spatial integration, with the placement of students with mild disabilities in the general class and the support of some of them out of this, the integration section. Furthermore, many interventions by diagnostic centers focus on individual pupils' deficits and aim at their treatment. However, inclusive education should mainly depend on the ability of the school to tackle diversity in an effective way. Greek universities and the Ministry of Education should provide opportunities for further training in special education to all teachers who are willing to be specialized. Courses and practical training on special education should be added in pre-graduation curriculums of university Departments of Education so that future teachers feel more strong and positive with inclusive education. Institute of Educational Policy through the project "Design and Development of Accessible Educational and Supervisory Material for Disabled Students" has adapted the school books for the first and second class of primary school so that they can be used by children with disabilities. This material has been developed in print and digital form with special educational software (Gelastopoulou and Kourbetis 2017). Adaptation of school textbooks for all classes of primary and secondary schools must be done so that they can be accessed by students with various disabilities and digitization of detection and diagnostic tools. This material will contribute to the better integration of children with disabilities, 
it will be used for teaching and training purposes, and will foster a sense of competence for teachers. E-books and digital educational applications and programs can really support the teaching and education of disabled students as they show more interest, attention, concentration, and enthusiasm and offer a lot to inclusive education.

The implementation of inclusive education is a complex process that requires, besides the proper legislation, the involvement of various factors in decision-making. In this direction, it is considered necessary to hire specialized educational and supportive staff for all school units and to increase funding for education. At the same time, it is considered necessary to remove stereotyped concepts of the past, in order to limit educational and social exclusion of disabled students. Finally, Greek decision makers and stakeholders should promote inclusive practices that seek to upgrading and modernizing the educational process.

Author Contributions: M.A.P. conceived of the presented idea. He was also responsible to verify the analytical methods. C.P. developed the theoretical framework. A.S.D. supervised the project. All authors discussed the results and contributed to the final manuscript.

Conflicts of Interest: The authors declare no conflict of interest.

\section{Appendix A. Questionnaire: “Teachers' Beliefs and Attitudes toward Inclusive Education”}

\section{Appendix A.1. Demographic Characteristics}

\section{Q1: Gender}

- Male

- Female

\section{Q2: Age}

- $\quad 20-30$

- $31-40$

- $41-50$

- $51-60$

Q3: Level of Teaching

- Kindergarten

- Primary School

- Secondary School

- Higher Education

Q4: Is there in your family a person with specific learning difficulties and disabilities?

- Yes

- No

Appendix A.2. Level of Confidence

Q5: How confident do you feel to teach students with specific learning difficulties and disabilities?

\begin{tabular}{ccccc}
\hline Strongly Disagree & Disagree & Undecided & Agree & Strongly Agree \\
\hline 1 & 2 & 3 & 4 & 5 \\
\hline
\end{tabular}

Appendix A.3. Attitudes towards Inclusion

Q6: Do you agree with the inclusion of the following students in mainstream schools? 


\begin{tabular}{|c|c|c|c|c|c|}
\hline & Strongly Disagree & Disagree & Undecided & Agree & Strongly Agree \\
\hline & 1 & 2 & 3 & 4 & 5 \\
\hline \multicolumn{6}{|l|}{ Students with mobility problems } \\
\hline \multicolumn{6}{|l|}{ Students with visual impairments } \\
\hline \multicolumn{6}{|l|}{ Students with speech problems } \\
\hline \multicolumn{6}{|l|}{ Students with comprehension problems } \\
\hline \multicolumn{6}{|l|}{ Student with aggressive behavior } \\
\hline \multicolumn{6}{|l|}{ Students with mental retardation } \\
\hline \multicolumn{6}{|l|}{ Students in the Autism Spectrum } \\
\hline
\end{tabular}

Appendix A.4. Expected Outcomes of Inclusion

Q7: Do you agree that students with learning difficulties and disabilities could benefit from their inclusion in mainstream schools?

\begin{tabular}{|c|c|c|c|c|c|}
\hline & Strongly Disagree & Disagree & Undecided & Agree & Strongly Agree \\
\hline \multicolumn{6}{|l|}{ In social interaction } \\
\hline \multicolumn{6}{|l|}{$\begin{array}{l}\text { In social development and } \\
\text { behavior }\end{array}$} \\
\hline \multicolumn{6}{|l|}{ In social skills } \\
\hline To enhance self-confidence & & & & & \\
\hline
\end{tabular}

Q8: Do you agree that students who attend mainstream schools could benefit from the inclusion of students with specific learning difficulties and disabilities?

\begin{tabular}{|c|c|c|c|c|c|}
\hline & Strongly Disagree & Disagree & Undecided & Agree & Strongly Agree \\
\hline \multicolumn{6}{|l|}{ In academic performance } \\
\hline \multicolumn{6}{|l|}{$\begin{array}{l}\text { In the development of social } \\
\text { consciousness }\end{array}$} \\
\hline $\begin{array}{l}\text { In the development of } \\
\text { sympathy }\end{array}$ & & & & & \\
\hline
\end{tabular}

Appendix A.5. Barriers to Inclusion

Q9: Do you agree that the following factors could be barriers to the implementation of Inclusive Education? 


\begin{tabular}{|c|c|c|c|c|c|}
\hline & Strongly Disagree & Disagree & Undecided & Agree & Strongly Agree \\
\hline & 1 & 2 & 3 & 4 & 5 \\
\hline \multicolumn{6}{|l|}{$\begin{array}{c}\text { Specialized Training in Special } \\
\text { Education }\end{array}$} \\
\hline \multicolumn{6}{|l|}{ Teacher's reluctance } \\
\hline \multicolumn{6}{|l|}{ Curriculum } \\
\hline \multicolumn{6}{|l|}{ School Unit Infrastructures } \\
\hline \multicolumn{6}{|l|}{ Parents' attitudes } \\
\hline \multicolumn{6}{|l|}{ Incomplete Funding } \\
\hline \multicolumn{6}{|l|}{ Legislative framework } \\
\hline \multicolumn{6}{|l|}{$\begin{array}{l}\text { Special and General teacher } \\
\text { collaboration }\end{array}$} \\
\hline \multicolumn{6}{|l|}{$\begin{array}{l}\text { Large number of children in the } \\
\text { classroom }\end{array}$} \\
\hline $\begin{array}{c}\text { Failure to provide appropriate } \\
\text { special education staff }\end{array}$ & & & & & \\
\hline
\end{tabular}

\section{Q10: Add a comment on Inclusive Education (optional)}

\section{Thank You!}

\section{References}

Ahmme, Masud, Umesh Sharma, and Joanne Deppeler. 2013. Impact of demographic variables and school support on teacher efficacy in inclusive classrooms in Bangladesh. The International Journal of Diversity in Education 12: 1-14. [CrossRef]

Ainscow, Mel. 2005. Developing inclusive education systems: What are the levers for change? Journal of Educational Change 6: 109-24. [CrossRef]

Ajuwon, Paul M. 2008. Inclusive Education for Students with Disabilities in Nigeria: Benefits, Challenges and Policy Implications. International Journal of Special Education 23: 11-16.

Alghazo, Emad M., Hamzah Dodeen, and Ibrahim A. Algaryouti. 2003. Attitudes of pre-service teachers towards persons with disabilities: Predictions for the success of inclusion. College Student Journal 37: 515-22.

Alghazo, Emad M., Naggar Gaad, and Eman El. 2004. General education teachers in the United Arab Emirates and their acceptance of the inclusion of students with disabilities. British Journal of Special Education 31: 94-99. [CrossRef]

Amr, Muna, Mayada Al-Natour, Bassam Al-Abdallat, and Hatem Alkhamra. 2016. Primary School Teachers' Knowledge, Attitudes and Views on Barriers to Inclusion in Jordan. International Journal of Special Education 31: 67-77.

Anastasiadou, Elisavet. 2016. Teacher's attitudes towards inclusion and the inclusion of students with emotional and behavioural disorders. Master's dissertation, University of Jyväskylä, Seminaarinkat, Finland.

Anastasiou, Dimitris, and James M. Kauffman. 2011. A social constructionist approach to disability: Implications for special education. Exceptional Children 77: 367-84. [CrossRef]

Antoniou, Alexandros Stamatios, Fotini Polychroni, and Christina Kotroni. 2009. Working with Students with Special Educational Needs in Greece: Teachers' Stressors and Coping Strategies. International Journal of Special Education 24: 100-11.

Armstrong, Derrick, Ann Cheryl Armstrong, and Ilektra Spandagou. 2011. Inclusion: By choice or by chance? International Journal of Inclusive Education 15: 29-39. [CrossRef]

Avramidis, Elias, and Efrosini Kalyva. 2007. The influence of teaching experience and professional development on Greek teachers' attitudes towards inclusion. European Journal of Special Needs Education 22: 367-89. [CrossRef]

Avramidis, Elias, and Brahm Norwich. 2002. Teachers' attitudes towards integration/inclusion: A review of the literature. European Journal of Special Needs Education 17: 129-47. [CrossRef]

Bablekou, Zoe, and Smaragda Kazi. 2016. Intellectual assessment of children and adolescents: The case of Greece. International Journal of School \& Educational Psychology 4: 225-30. 
Batsiou, Sofia, Evangelos Bebetsos, P. Panteli, and Panos Antoniou. 2008. Attitudes and intention of Greek and Cypriot primary education teachers towards teaching pupils with special educational needs in mainstream schools. International Journal of Inclusive Education 12: 201-19. [CrossRef]

Bhatnagar, Nisha, and Ajay Das. 2014. Attitudes of secondary school teachers towards inclusive education in New Delhi, India. Journal of Research in Special Educational Needs 14: 255-63. [CrossRef]

Bornman, Juan, and Dana K. Donohue. 2013. South African teachers' attitudes toward learners with barriers to learning: Attention-deficit and hyperactivity disorder and little or no functional speech. International Journal of Disability, Development and Education 60: 85-104. [CrossRef]

Brown, Zeta, ed. 2016. Inclusive Education: Perspectives on Pedagogy, Policy and Practice. Abingdon: Routledge.

Chhabra, Simmi, Rama Srivastava, and Ishaan Srivastava. 2010. Inclusive education in Botswana: The perceptions of school teachers. Journal of Disability Policy Studies 20: 219-28. [CrossRef]

Coutsocostas, Georgia Gloria, and Alison Alborz. 2010. Greek mainstream secondary school teachers' perceptions of inclusive education and of having pupils with complex learning disabilities in the classroom/school. European Journal of Special Needs Education 25: 149-64. [CrossRef]

De Boer, Anke, S. J. Pijl, and A. Minnaert. 2011. Regular primary schoolteachers' attitudes towards inclusive education: A review of the literature. International Journal of Inclusive Education 15: 331-53. [CrossRef]

De Boer, A., Sip Jan Pijl, and Alexander Minnaert. 2012. Students' attitudes towards peers with disabilities: A review of the literature. International Journal of Disability, Development and Education 59: 379-92. [CrossRef]

Dessemontet, Rachel Sermier, Válerie Benoit, and Gérard Bless. 2011. Schulische Integration von Kindern mit einer geistigen Behinderung- Untersuchung der Entwicklung der Schulleistungen und der adaptiven Fähigkeiten, der Wirkung auf die Lernentwicklung der Mitschüler sowie der Lehrereinstellung zur Integration. Empirische Sonderpädagogik 4: 291-307.

Ellins, Jean, and Jill Porter. 2005. Departmental differences in attitudes to special educational needs in the secondary school. British Journal of Special Education 32: 188-95. [CrossRef]

European Agency for Development in Special Needs Education. 2010. Special Needs Education Country Data 2010, Odense, Denmark: European Agency for Development in Special Needs Education. Brussels: European Agency for Development in Special Needs Education.

European Agency for Development in Special Needs Education. 2012. Special Needs Education Country Data 2012. Odense: Author. Available online: http:/ /www.european-agency.org/sites/default/files/sne-country-data2012_SNE-Country-Data2012.pdf (accessed on 7 August 2015).

Findler, Liora, Noa Vilchinsky, and Shirli Werner. 2007. The multidimensional attitudes scale toward persons with disabilities (MAS) construction and validation. Rehabilitation Counseling Bulletin 50: 166-76. [CrossRef]

Forlin, Chris, and Dianne Chambers. 2011. Teacher preparation for inclusive education: Increasing knowledge but raising concerns. Asia-Pacific Journal of Teacher Education 39: 17-32. [CrossRef]

Forlin, Chris, Tim Loreman, Umesh Sharma, and Chris Earle. 2009. Demographic differences in changing pre-service teachers' attitudes, sentiments and concerns about inclusive education. International Journal of Inclusive Education 13: 195-209. [CrossRef]

Fyssa, Aristea, and Anastasia Vlachou. 2015. Assessment of quality for inclusive programs in Greek preschool classrooms. Journal of Early Intervention 37: 190-207. [CrossRef]

Fyssa, Aristea, Anastasia Vlachou, and Elias Avramidis. 2014. Early childhood teachers' understanding of inclusive education and associated practices: Reflections from Greece. International Journal of Early Years Education 22: 223-37. [CrossRef]

Gal, Eynat, Naomi Schreur, and Batya Engel-Yeger. 2010. Inclusion of Children with Disabilities: Teachers' Attitudes and Requirements for Environmental Accommodations. International Journal of Special Education 25: 89-99.

Gasteiger-Klicpera, Barbara, Christian Klicpera, Markus Gebhardt, and Susanne Schwab. 2013. Attitudes and experiences of parents regarding inclusive and special school education for children with learning and intellectual disabilities. International Journal of Inclusive Education 17: 663-81. [CrossRef]

Gebhardt, Markus, Susanne Schwab, Hannelore Reicher, Barbara Ellmeier, Sonja Gmeiner, Peter Rossmann, and Barbara Gasteiger Klicpera. 2011. Einstellungen von LehrerInnen zur schulischen Integration von Kindern mit einem sonderpädagogischen Förderbedarf in Österreich. Empirische Sonderpädagogik 4: 275-90.

Gelastopoulou, Maria, and Vassilis Kourbetis. 2017. The use of Information and Communication Technologies for inclusive education in Greece. In Research on e-Learning and ICT in Education. Cham: Springer, pp. 243-55. 
Gething, Lindsay, Barbara Wheeler, Jean Cote, Adrian Furnham, Jasna Hudek-Knezevic, Martin Kumpf, Jarek Rola, and Ken Sellick. 1997. An international validation of the interaction with disabled persons scale. International Journal of Rehabilitation Research. Internationale Zeitschrift fur Rehabilitationsforschung. Revue Internationale de Recherches de Readaptation 20: 149-58. [CrossRef] [PubMed]

Gilmore, Linda, Jennifer Campbell, and Monica Cuskelly. 2003. Developmental expectations, personality stereotypes, and attitudes towards inclusive education: Community and teacher views of Down syndrome. International Journal of Disability, Development and Education 50: 65-76. [CrossRef]

Glazzard, Jonathan. 2011. Perceptions of the barriers to effective inclusion in one primary school: Voices of teachers and teaching assistants. Support for Learning 26: 56-63. [CrossRef]

Hodkinson, Alan. 2006. Conceptions and misconceptions of inclusive education-one year on: A critical analysis of Newly Qualified Teachers' knowledge and understanding of inclusion. Research in Education 76: 43-55. [CrossRef]

Hodkinson, Alan, and Chandrika Devarakonda. 2009. Conceptions of inclusion and inclusive education: A critical examination of the perspectives and practices of teachers in India. Research in Education 82: 85-99. [CrossRef]

Hofman, Roelande H., and Judith S. Kilimo. 2014. Teachers' attitudes and self-efficacy towards inclusion of pupils with disabilities in Tanzanian schools. Journal of Education and Training 1: 177-98. [CrossRef]

Hornby, Garry. 1999. Hornby, Garry 1999. Inclusion or delusion: Can one size fit all? Support for Learning 14: 152-57. [CrossRef]

Katz, Jennifer, and Pat Mirenda. 2002. Including students with developmental disabilities in general education classrooms: Educational benefits. International Journal of Special Education 17: 14-24.

Kim, Ji Ryun. 2011. Influence of teacher preparation programmes on preservice teachers' attitudes toward inclusion. International Journal of Inclusive Education 15: 355-77. [CrossRef]

Knight, Jim. 2002. Crossing boundaries: What constructivists can teach intensive-explicit instructors and vice versa. Focus on Exceptional Children 35: 1-16. [CrossRef]

Koutrouba, Konstantina, Malvina Vamvakari, and Helen Theodoropoulos. 2008. SEN students' inclusion in Greece: Factors influencing Greek teachers' stance. European Journal of Special Needs Education 23: 413-21. [CrossRef]

Lambe, Jackie, and Robert Bones. 2007. The effect of school-based practice on student teachers' attitudes towards inclusive education in Northern Ireland. Journal of Education for Teaching 33: 99-113. [CrossRef]

Lambropoulou, Vassiliki. 2004. Report on the Action "Mapping of Special Education". Athens: Pedagogical Institute, pp. 2-3.

Leatherman, Jane M. 2007. "I Just See All Children as Children": Teachers' Perceptions About Inclusion. The Qualitative Report 12: 594-611.

Leatherman, Jane M., and Judith A. Niemeyer. 2005. Teachers' attitudes toward inclusion: Factors influencing classroom practice. Journal of Early Childhood Teacher Education 26: 23-36. [CrossRef]

Lindsay, Geoff. 2003. Inclusive education: A critical perspective. British Journal of Special Education 30: 3-12. [CrossRef]

Malinen, Olli Pekka, Hannu Savolainen, and Jiacheng Xu. 2012. Beijing in-service teachers' self-efficacy and attitudes towards inclusive education. Teaching and Teacher Education 28: 526-34. [CrossRef]

O'Hanlon, Christine. 2013. Inclusive education in Spain and Greece. In Equality and Diversity in Education 2: National and International Contexts for Practice and Research. Abingdon: Routledge, p. 116.

Persson, Bengt. 2006. Pathways to Inclusion: A guide to staff development. European Educational Research Journal 5 : 152-58. [CrossRef]

Polat, Filiz. 2011. Inclusion in education: A step towards social justice. International Journal of Educational Development 31: 50-58. [CrossRef]

Rakap, Salih, and Louise Kaczmarek. 2010. Teachers' attitudes towards inclusion in Turkey. European Journal of Special Needs Education 25: 59-75. [CrossRef]

Rea, Patricia J., Virginia L. McLaughlin, and Chriss Walther-Thomas. 2002. Outcomes for students with learning disabilities in inclusive and pullout programs. Exceptional Children 68: 203-22. [CrossRef]

Robinson, Deborah. 2017. Effective inclusive teacher education for special educational needs and disabilities: Some more thoughts on the way forward. Teaching and Teacher Education 61: 164-78. [CrossRef] 
Romi, Shlomo, and Yona Leyser. 2006. Exploring inclusion preservice training needs: A study of variables associated with attitudes and self-efficacy beliefs. European Journal of Special Needs Education 21: 85-105. [CrossRef]

Ruijs, Nienke M., Ineke Van der Veen, and Thea T. Peetsma. 2010. Inclusive education and students without special educational needs. Educational Research 52: 351-90. [CrossRef]

Savolainen, Hannu, Petra Engelbrecht, Mirna Nel, and Olli Pekka Malinen. 2012. Understanding teachers' attitudes and self-efficacy in inclusive education: Implications for pre-service and in-service teacher education. European Journal of Special Needs Education 27: 51-68. [CrossRef]

Scruggs, Thomas E., and Margo A. Mastropieri. 1996. Teacher perceptions of mainstreaming/inclusion, 1958-1995: A research synthesis. Exceptional Children 63: 59-74. [CrossRef]

Sharma, Umesh, Jessie Ee, and Ishmar Desai. 2003. A comparison of Australian and Singaporean pre-service teachers' attitudes and concerns about inclusive education. Teaching and Learning 24: 207-17.

Sharma, Umesh, Chris Forlin, and Tim Loreman. 2008. Impact of training on pre-service teachers' attitudes and concerns about inclusive education and sentiments about persons with disabilities. Disability $\mathcal{E}$ Society 23: 773-85.

Siegel, Janna, and Norbert Jausovec. 1994. Improving Teachers' Attitudes toward Students with Disabilities. The Teacher Educator 31: 304-12.

Subban, Pearl, and Umesh Sharma. 2005. Understanding educator attitudes toward the implementation of inclusive education. Disability Studies Quarterly, 25. [CrossRef]

Subban, Pearl, and Umesh Sharma. 2006. Primary school teachers' perceptions of inclusive education in Victoria, Australia. International Journal of Special Education 21: 42-52.

Tafa, Eufimia, and George Manolitsis. 2003. Attitudes of Greek parents of typically developing kindergarten children towards inclusive education. European Journal of Special Needs Education 18: 155-71. [CrossRef]

Tsakiridou, Helen, and Konstantia Polyzopoulou. 2014. Greek teachers' attitudes toward the inclusion of students with special educational needs. American Journal of Educational Research 2: 208-18. [CrossRef]

Warnock Committee. 1978. Special Educational Needs: The Warnock Report. London: DES.

Warnock, Mary, Brahm Norwich, and Lorella Terzi, eds. 2010. Special Educational Needs: A New Look: Key Debates in Educational Policy. London: Bloomsbury Publishing, pp. 4-32.

Woodcock, Stuart. 2013. Trainee teachers' attitudes towards students with specific learning disabilities. Australian Journal of Teacher Education 38: 16-29. [CrossRef]

Yada, Akie, and Hannu Savolainen. 2017. Japanese in-service teachers' attitudes toward inclusive education and self-efficacy for inclusive practices. Teaching and Teacher Education 64: 222-29. [CrossRef]

Zoniou-Sideri, Athina, Eudoxia Deropoulou-Derou, Panagiota Karagianni, and Ilektra Spandagou. 2006. Inclusive discourse in Greece: Strong voices, weak policies. International Journal of Inclusive Education 10: $279-91$. [CrossRef]

Zoniou-Sideri, Athina, and Anastasia Vlachou. 2006. Greek teachers' belief systems about disability and inclusive education. International Journal of Inclusive Education 10: 379-94. [CrossRef]

(c) 2018 by the authors. Licensee MDPI, Basel, Switzerland. This article is an open access article distributed under the terms and conditions of the Creative Commons Attribution (CC BY) license (http:/ / creativecommons.org/licenses/by/4.0/). 